\title{
Independent and combined cytotoxicity and genotoxicity of triethylene glycol dimethacrylate and urethane dimethacrylate
}

\author{
Maria Wisniewska-Jarosinska $\cdot$ Tomasz Poplawski • \\ Cezary J. Chojnacki $\cdot$ Elzbieta Pawlowska • \\ Renata Krupa $\cdot$ Joanna Szczepanska $\cdot$ Janusz Blasiak
}

Received: 2 September 2010/Accepted: 20 November 2010/Published online: 3 December 2010

(C) The Author(s) 2010. This article is published with open access at Springerlink.com

\begin{abstract}
Dental composite materials contain polymers of methacrylates, which, due to mechanical abrasion and enzymatic action of saliva, may release their monomers into oral cavity and the pulp. Moreover, polymerization is always incomplete and leaves usually considerable fraction of free monomers. Mechanisms of the genotoxicity of methacrylate monomers have been rarely explored. As the polymerization of a monomer is catalyzed by a co-monomer, their combined action should be considered. In the present work, we investigated cytotoxic and genotoxic effects of urethane dimethacrylate (UDMA), often used as a monomer, at $1 \mathrm{mM}$, and triethylene glycol dimethacrylate (TEGDMA), a typical co-monomer, at $5 \mathrm{mM}$ singly and in combination. Experiments were conducted on Chinese hamster ovary cells. Cell viability, apoptosis and cell cycle were assessed by flow cytometry, whereas DNA damage was evaluated by plasmid conformation test and comet assay. Both compounds decreased the viability of the cells, but did not induce strand breaks in an isolated plasmid DNA. However, both substances, either singly or in combination, damaged DNA in CHO cells as evaluated by comet assay. Both compounds induced apoptosis, but a combined action of them led to a decrease in the number of
\end{abstract}

M. Wisniewska-Jarosinska · C. J. Chojnacki

Department of Gastroenterology and Internal Medicine, Medical

University of Lodz, 1 Haller's Square, 90-647 Lodz, Poland

T. Poplawski $\cdot$ R. Krupa $\cdot$ J. Blasiak ( $₫)$

Department of Molecular Genetics, University of Lodz,

Banacha 12/16, 90-237 Lodz, Poland

e-mail: jblasiak@biol.uni.lodz.pl

E. Pawlowska $\cdot$ J. Szczepanska

Department of Pediatric Dentistry, Medical University of Lodz, Pomorska 251, 92-216 Lodz, Poland apoptotic cells. The combined action of UDMA and TEGDMA in the disturbance of cell cycle was lesser compared to the action of each compound individually. Individually, though UDMA and TEGDMA may induce cytotoxic and genotoxic, however, a combination of both does not produce a significant increase in these effects.

Keywords Dental restorative materials - Urethane dimethacrylate - Triethylene glycol dimethacrylate . Genotoxicity · Cytotoxicity

\section{Introduction}

Composite methacrylate resin-based materials are a mixture of organic polymers with embedded inorganic particles. However, the residual monomers can be released from the polymeric matrix and enter the oral cavity and the pulp, from where they can migrate into the bloodstream [1-3]. Migration into the pulp is facilitated by the microchannels present in the dentin. This is a serious problem because the degree of monomer/polymer conversion varies between 35 and $77 \%[4,5]$. The amount of released monomers ranges from micrograms to milligrams, corresponding to their concentrations in the pulp as high as $8 \mathrm{mmol} / \mathrm{l}$ [6-8]. These are hypothetical, maximal concentrations of monomers, but they should be taken into account as possibly occurring locally. It is not easy to estimate the concentration of monomers in blood and other tissues of the organism, but their high potential concentration in the pulp may result in their considerably high concentration in the rest of the organism. But from the genotoxic point of view, even the presence of a small amount of a reactive methacrylate monomer may be enough, resulting in the transformation of the cell, leading to a pathological phenotype or cell death. 
The first signals on potential hazard of methacrylates came from the dental personnel and subsequent research showed several work-related, mainly immunological, harmful effects induced by these compounds $[9,10]$. Subsequent studies revealed a variety of potential toxic effects evoked by the methacrylates releasing (leaching) from dental restoratives. These included also genotoxic effects [6]. However, few studies concentrated on the direct or indirect DNA-damaging action of methacrylates, lying at the heart of the genotoxicity. Schweikl et al. showed that triethylene glycol dimethacrylate (TEGDMA) induced DNA deletions [11], whereas Kleinsasser et al. demonstrated the ability of TEGDMA to induce DNA damage [12]. Recently, we showed that glycidyl methacrylate (GMA) induced DNA damage, including double strand breaks in human lymphocytes, at concentrations, which did not substantially affect the viability of the cells [13]. GMA induced also apoptosis and disturbed the cell cycle, but it was not able to interact with an isolated plasmid DNA. Urcan et al. [14] demonstrated that all most common composite resins bisphenol A glicidyl methacrylate (BisGMA), urethane dimethacrylate (UDMA), TEGMA, and 2-hydroxyethylmethacrylate (HEMA) are able to induce double strand DNA breaks in human gingival fibroblasts. UDMA is one of the commonly used dental restorative materials, as multifunctional urethane methacrylates produce densely crosslinked networks with a high thermal stability and mechanical strength. The photopolymerization of UDMA results in flexible materials, and it is mostly used in combination with the less flexible Bis-GMA [15].

Resin composite and dental bondings contain base monomers and co-monomers to influence viscosity and bonding strength of these components. The former are usually Bis-GMA and UDMA, whereas the latter are commonly HEMA and TEGDMA. Therefore, it is important to evaluate combined biological effects of base monomers and co-monomers, because they can mutually influence their action and may produce a synergistic effect, sometimes considerably different from that expected. In the present work, we investigated cytotoxic and genotoxic effects of combined action of TEGDMA and UDMA in hamster ovary cells, CHO-K1, assessing the cells' viability, DNA damage, apoptosis and cell cycle.

\section{Materials and methods}

Chemicals

UDMA and TEGDMA of 95\% purity were obtained from Aldrich (Steinheim, Germany). Plasmid DNA purification kit was provided by EURx (Gdansk, Poland). Cell viability, apoptosis and cell cycle kits were purchased from BD
Biosciences (San Jose, CA, USA). Low melting point (LMP) and normal melting point (NMP) agarose, phosphate buffered saline (PBS), 4',6-diamidino-2-phenylindole (DAPI), dimethyl sulfoxide (DMSO), fetal bovine serum (FBS), MTT, lectin, penicillin, streptomycin, Bradford reagent were purchased from Sigma (St. Louis, MO, USA). PstI restriction enzyme was from Fermentas (Hanover, MD, USA). All other chemicals were of the highest commercial grade available.

\section{Cells}

Chinese hamster ovary cells, CHO-K1, were obtained from American Type Culture Collection (Manassas, VA, USA). The cells were grown in HAM's medium without L-glutamine supplemented with $10 \%$ FCS, L-glutamine with penicillin and streptomycin at $1 \%$ in a $5 \% \mathrm{CO}_{2}$ atmosphere at $37^{\circ} \mathrm{C}$. Escherichia coli cells, strain DH5 $\alpha$ with the pUC19 plasmid, were grown in a $\mathrm{LB}$ broth at $37^{\circ} \mathrm{C}$ overnight.

\section{Cell treatment}

TEGDMA at a final concentration of $5 \mathrm{mM}$ was added to the cells in RPMI 1640 from its $1 \mathrm{M}$ solution in DMSO. The final concentration of DMSO in the samples did not exceed $0.36 \%$, which did not influence the processes under study. UDMA was taken from a $1 \mathrm{M}$ stock solution and dissolved in DMSO to a final concentration of $1 \mathrm{mM}$ with the final DMSO concentration of $0.15 \%$. The control cells received only the growth medium and DMSO at $0.51 \%$. To examine DNA damage and cell viability, the cells were incubated with the agent(s) for $1 \mathrm{~h}$ at $37^{\circ} \mathrm{C}$. Each experiment included a positive control, which was hydrogen peroxide $\mathrm{H}_{2} \mathrm{O}_{2}$ at $20 \mu \mathrm{M}$ for 15 min on ice. $\mathrm{H}_{2} \mathrm{O}_{2}$ produced a pronounced DNA damage, which resulted in the tail DNA of $30-40 \%$.

\section{Cell viability}

The BD Cell Viability Kit was used. The kit contains thiazole orange (TO) solution to stain all cells and propidium iodide (PI) to stain dead cells. Aliquots of $2.0 \mu \mathrm{l}$ of TO and $1.0 \mu \mathrm{l}$ of PI were added to $1 \mathrm{ml}$ of cell suspension containing $5 \times 10^{5}$ cells, producing the final staining concentrations of $84 \mathrm{nM}$ and $4.3 \mu \mathrm{M}$, respectively. The mixture was gently shaken and incubated for $5 \mathrm{~min}$ at room temperature to allow both dyes to enter the cells. The samples were acquired on a LSRII (Becton Dickinson, San Jose, USA) flow cytometer equipped with $488 \mathrm{~nm}$ laser excitation and BD FACSDiva software $\mathrm{v}$ 4.1.2. Fifty thousand cells were analyzed in each experiment and the experiments were carried out thrice. The samples were coded prior to measurements in order to prevent the 
investigator from knowing the exposure mode for any particular sample.

\section{Plasmid relaxation assay}

pUC19 plasmids were isolated from DH5 $\alpha$ E. coli cells with GeneJET Plasmid Miniprep Kit (Fermentas, Burlington, Ontario, Canada) according to the manufacturer's instructions. Plasmids were exposed to UV irradiation at $35 \mathrm{~J} / \mathrm{m}^{2}$ (positive control) to check the migration of its multimeric forms (supercoiled, nicked circular and linear). The linear form was identified by digestion of the plasmid with the PstI restriction enzyme. UV irradiation induced strand breaks in DNA and caused the relaxation of supercoiled plasmid - one break was enough to relax one molecule of the plasmid. Structural differences between supercoiled, nicked circular and linear forms of the plasmid accounted for their different electrophoretic mobility. Plasmid samples at $150 \mathrm{ng} / \mu \mathrm{l}$ were subjected to a $1 \%$ agarose gel electrophoresis carried out in TAE (Trisacetate-EDTA) buffer. The gel was stained with ethidium bromide $(0.5 \mathrm{mg} / \mathrm{ml})$ and the plasmid DNA was visualized under ultraviolet light (302 nm), scanned by a CCD camera, and densitometry analysis was performed with the GeneTools by Syngene (Cambridge, UK) software. The ability of UDMA and TEGDMA to damage DNA was quantified by calculating the ratio of the open circular DNA to the total amount of DNA (R). The values for supercoiled DNA were multiplied by 1.66 to correct for the decreased intercalating ability of ethidium bromide [16].

\section{Comet assay}

The comet assay was performed under alkaline conditions essentially according to the procedure of Singh et al. [17] with modifications [18] as described previously [13]. A freshly prepared suspension of cells in $0.75 \%$ LMP agarose dissolved in PBS was spread onto microscope slides precoated with $0.5 \%$ NMP agarose. The cells were then lysed for $1 \mathrm{~h}$ at $4^{\circ} \mathrm{C}$ in a buffer consisting of $2.5 \mathrm{M} \mathrm{NaCl}$, $100 \mathrm{mM}$ EDTA, 1\% Triton X-100, $10 \mathrm{mM}$ Tris, $\mathrm{pH} 10$. After lysis, the slides were placed in an electrophoresis unit and the DNA was allowed to unwind for $40 \mathrm{~min}$ in the electrophoretic solution consisting of $300 \mathrm{mM} \mathrm{NaOH}$, $1 \mathrm{mM}$ EDTA, $\mathrm{pH}>13$. Electrophoresis was conducted at $4^{\circ} \mathrm{C}$ (the temperature of the running buffer did not exceed $12^{\circ} \mathrm{C}$ ) for $20 \mathrm{~min}$ at an electric field strength of $0.73 \mathrm{~V} / \mathrm{cm}$ (29 mA). The slides were then neutralized with $0.4 \mathrm{M}$ Tris, $\mathrm{pH} 7.5$, stained with $2 \mu \mathrm{g} / \mathrm{ml}$ DAPI and covered with cover slips. To prevent additional DNA damage, all the steps described above were conducted under dimmed light or in the dark.
In the neutral version of the comet assay, electrophoresis was run in a buffer consisting of $100 \mathrm{mM}$ Tris and $300 \mathrm{mM}$ sodium acetate at $\mathrm{pH}$ adjusted to 9.0 by glacial acetic acid [19]. Electrophoresis was conducted for $60 \mathrm{~min}$, after a 20 min equilibrium period, at electric field strength of $0.41 \mathrm{~V} / \mathrm{cm}(50 \mathrm{~mA})$ at $4^{\circ} \mathrm{C}$.

The slides were examined at $200 \times$ magnification in an Eclipse fluorescence microscope (Nikon, Tokyo, Japan) attached to a COHU 4910 video camera (Cohu, Inc., San Diego, CA) equipped with a UV filter block consisting of an excitation filter $(359 \mathrm{~nm})$ and barrier filter $(461 \mathrm{~nm})$ and connected to a personal computer-based image analysis system, Lucia-Comet v. 4.51 (Laboratory Imaging, Praha, Czech Republic). Fifty images were randomly selected from each sample and the comet tail DNA was measured. Two parallel tests with aliquots of the same sample of cells were performed for a total of 100 cells. Each experiment was repeated three times. The percentage of DNA in the tail (\% tail DNA) was analyzed. This quantity is positively correlated with the level of DNA breakage or/and alkali labile sites in the cell and is negatively correlated with the level of DNA crosslinks [20]. For the neutral version, this $\%$ tail DNA positively correlates with DNA double strand breaks. The mean value of the \% tail DNA in a particular sample was taken as an index of the DNA damage in this sample.

\section{Apoptosis}

The BD Annexin V-FITC Apoptosis Detection Kit I was used. The kit contains Annexin V conjugated to the flurochrome FITC. This complex displays a high affinity to the membrane phospholipid phosphatidylserine, which undergoes externalization in the earlier stages of apoptosis. To distinguish early apoptotic cells from dead cells resulted from late apoptosis or necrosis, the vital dye PI was used. In this way, cells that are viable are Annexin V-FITC and PI negative, cells in early apoptosis are Annexin-FITC positive and PI negative and cells in late apoptosis or already dead are both Annexin-FITC and PI positive. Therefore, this assay does not distinguish, per se, between cells that have already undergone apoptotic death and those that have died as a result of necrosis because in either case, the dead cells will stain with both dyes.

Three experiments of $5 \times 10^{4}$ measurements each were performed. The cells were incubated with UDMA or/and TGDMA for $6 \mathrm{~h}$, washed in cold PBS, centrifuged (15 min, $280 \mathrm{~g}, 4^{\circ} \mathrm{C}$ ) and resuspended in $100 \mu \mathrm{l}$ of $1 \times$ binding buffer. Then, $5 \mu \mathrm{l}$ of Annexin V-FITC and $5 \mu \mathrm{l}$ of PI were added to cells. The mixture was gently vortexed and incubated for $15 \mathrm{~min}$ at room temperature in the dark. Next, $400 \mu \mathrm{l}$ of $1 \times$ binding buffer was added to each tube and samples were analyzed by flow cytometry as described 
earlier. Quadrant settings were based on control samples, exposed to ethanol. The lower left quadrant (Annexin V-FITC and PI negative) corresponded to viable cells not undergoing apoptosis, upper left (Annexin V-FTIC negative and PI positive) - cells in early stage of apoptosis, lower right (Annexin V-FTIC positive and PI negative)cells undergoing apoptosis, upper right (Annexin V-FTIC and PI positive) - cells that were in end stage of apoptosis or already dead. The apoptosis was expressed as a ratio of the number of early and late apoptotic cells (upper left and lower right quadrants) to the number of cells with no measurable apoptosis (lower left quadrant).

\section{Cell cycle}

The CycleTEST PLUS DNA Reagent Kit was used to determine the DNA index (DI) and cell-cycle phase distributions. The method involved dissolving of the cell membrane lipids, eliminating the cell cytoskeleton with trypsin, digesting the cellular RNA and stabilizing the chromatin with spermine. Propidium iodine was bound to isolated nuclei, which were then run on the LSRII flow cytometer, emitting fluorescence in the range $580-650 \mathrm{~nm}$ and equipped with a 585/42 filter to analyze the light emitted between 564 and $606 \mathrm{~nm}$ by the stained cells. The DI was obtained by dividing the mean of the relative content of the exposed $\mathrm{G}_{0} / \mathrm{G}_{1}$ population by the mean of the control $\mathrm{G}_{0} / \mathrm{G}_{1}$ population.

Suspension of cells was washed three times in Buffer Solution, adjusted to the concentration of $10^{6}$ cells $/ \mathrm{ml}$ and then stained according to the manufacturer's instructions. Results were analyzed by CellFIT software.

Data analysis

The values in this study were expressed as mean \pm SEM from three experiments, i.e. the data from three experiments were pooled and the statistical parameters were calculated. The data obtained from cell viability were expressed as mean $\pm \mathrm{SD}$. The Mann-Whitney $U$-test was used to determine differences between samples with the abnormal distribution (Kolmogorov-Smirnov test). The differences between samples with the normal distribution were evaluated by applying the Student's $t$-test.

\section{Results}

Cell viability

UDMA at $1 \mathrm{mM}$ decreased the viability of the $\mathrm{CHO}$ cells, as compared to the unexposed cells (89.9 vs. 96.4\%), which was statistically significant $(P<0.001)$. TEGDMA

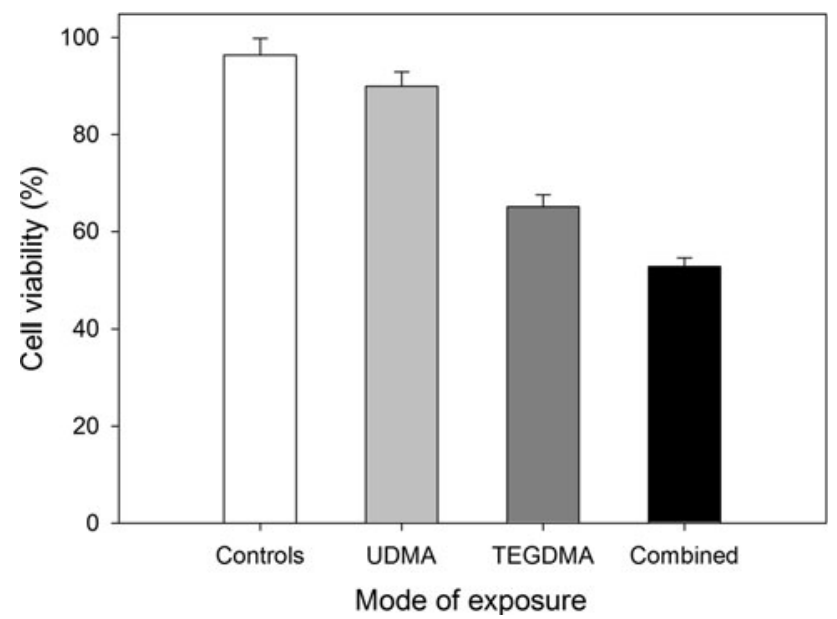

Fig. 1 Viability of Chinese hamster ovary CHO-K1 cells exposed for $1 \mathrm{~h}$ at $37^{\circ} \mathrm{C}$ to $1 \mathrm{mM}$ urethane dimethacrylate (UDMA), $5 \mathrm{mM}$ triethylene glycol dimethacrylate (TEGDMA) singly or in combination, measured by flow cytometry with thiazole orange and propidium iodide. Displayed is the mean of three experiments of $5 \times 10^{4}$ measurements each, error bars denote standard deviation. For all modes of exposure $P<0.001$ as compared to the unexposed control

at $5 \mathrm{mM}$ also decreased the viability, but to a much higher extent, $65 \%(P<0.001)$. The decrease dropped to $52 \%$, when both substances acted simultaneously $(P<0.001)$ (Fig. 1).

DNA damage in vitro

UDMA and TEGDMA, either singly or in combination, did not introduce DNA breaks to isolated DNA, as assessed by the plasmid relaxation assay, in which the ratio of the amount of open circular form of plasmid DNA to the total amount of DNA was calculated (Fig. 2, $P>0.05$ ). The plasmid used in our experiment was sensitive to UV radiation causing it relaxation $(P<0.001)$.

\section{DNA damage in $\mathrm{CHO}$ cells}

Figure 3 displays the dependence of DNA damage on the mode of exposure of the $\mathrm{CHO}$ cells in the alkaline version of the comet assay. This version enables detecting single and double DNA strand breaks as well as alkali labile sites. Both UDMA and TEGDMA evoked a significant DNA damage (tail DNA 11.8 and 9.7\%, respectively) and combined action of these compounds resulted in the $11.9 \%$ tail DNA. There was not a significant difference between the effect evoked by either compound singly and their combined action $(P>0.05)$.

We performed also the neutral version of the comet assay, which detects DNA double strand breaks. In fact, this version is not specific for double strand breaks and single strand breaks may also contribute to the signal 


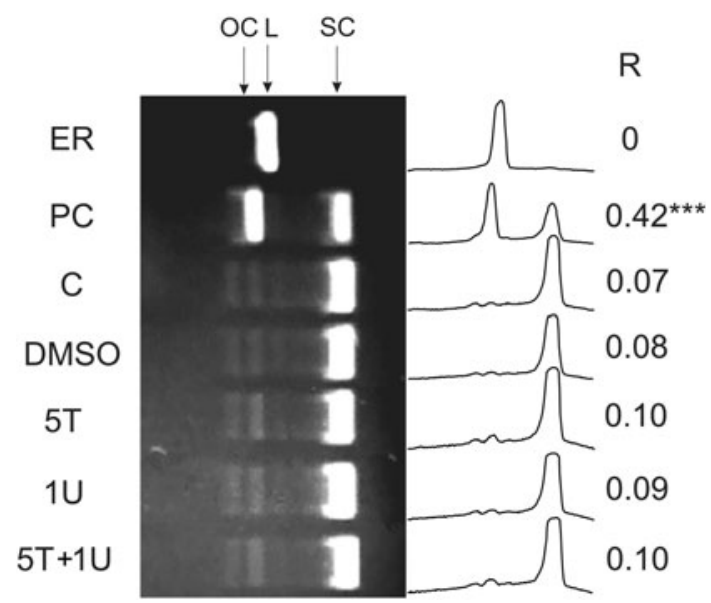

Fig. 2 DNA damage in an isolated pUC19 plasmid exposed to urethane dimethacrylate (UDMA) and triethylene glycol dimethacrylate (TEGDMA). The picture shows three forms of the plasmid: open circular (OC), linear (L) and supercoiled (SC) exposed to $1 \mathrm{mM}$ UDMA (1U), $5 \mathrm{mM}$ TEGDMA (5T) singly and in combination $(5 \mathrm{~T}+1 \mathrm{U})$ or $\mathrm{UV}$ at $35 \mathrm{~J} / \mathrm{m}^{2}$ as a positive control (PC). Plasmid was linearized with the PstI restriction enzyme (ER) and C denotes unexposed (control) DNA. Additionally, samples with DMSO at $0.51 \%$, used as a solvent for UDMA and TEGDMA, were analyzed. The samples were run on a $1 \%$ agarose gel, stained with ethidium bromide and visualized in UV light. Densitometric scans of the gel lanes are presented on the right along with the ratio of the open circular and linear plasmid DNA to the total amount of DNA (R) as a measure of DNA damage. Presented is the average of three independent measurements, $* * * P<0.001$ as compared with the unexposed control

detected in the neutral version, but when double strand are present, they would increase the percentage of DNA in the tail. We did not observe any change in the tail DNA in any mode of exposure (data not shown). So, we conclude that neither UDMA at $1 \mathrm{mM}$, nor TEGDMA at $5 \mathrm{mM}$ singly or in combination induced double strand breaks in the $\mathrm{CHO}$ cells.

\section{Apoptosis}

Both UDMA and TEGDMA singly induced a pronounced increase in the apoptotic ratio of the $\mathrm{CHO}$ cells $(P<0.001$, Fig. 4). UDMA increased the ratio almost 10 times, and TEGDMA—over 12. However, the increase induced by combined action of both methacrylates was not so highonly 2.5 times-but it was still statistically significant $(P<0.05)$. Untreated cells were primarily Annexin V-FITC- and PI-negative, indicating that they were viable and not undergoing apoptosis. After incubation with either methacrylate singly a major fraction of the cells became V-FTIC and PI positive, indicating that they were in the end stage of apoptosis or already dead. Combined action of both compounds made a significant part of the cells remain in the early stage of apoptosis.

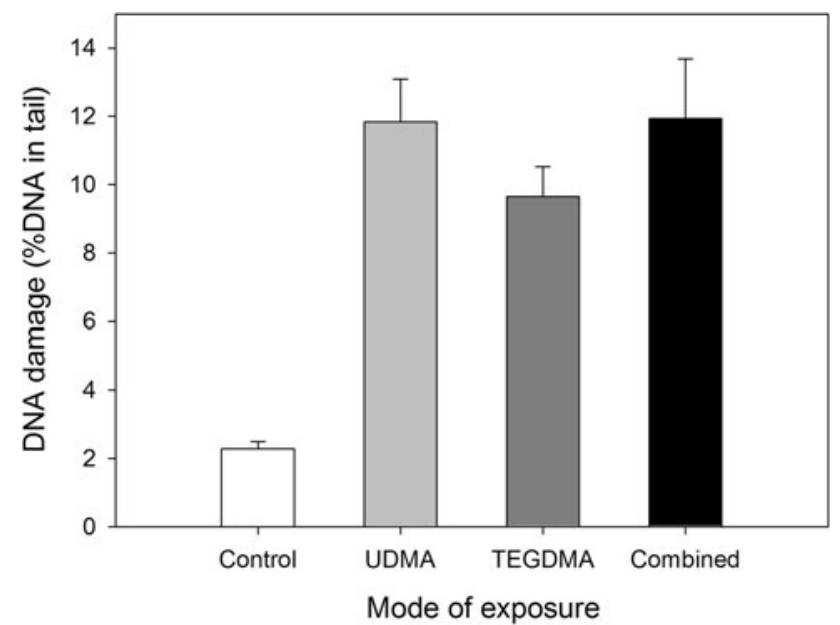

Fig. 3 DNA damage of Chinese hamster ovary cells CHO-K1 exposed for $1 \mathrm{~h}$ at $37^{\circ} \mathrm{C}$ to $1 \mathrm{mM}$ urethane dimethacrylate (UDMA, light gray bars), $5 \mathrm{mM}$ triethylene glycol dimethacrylate (TEGDMA, dark gray bars) singly or in combination (black bars) measured as percentage in the tail DNA in comets of alkaline comet assay. The mean value for one hundred cells analyzed in each treatment in three independent experiments is displayed, error bars represent SEM, $P<0.001$ for all modes of exposure as compared with unexposed controls

\section{Cell cycle}

UDMA at $1 \mathrm{mM}$ and TEGDM at $5 \mathrm{mM}$ singly evoked similar changes in the progression of the cell cycle of CHO-K1 cells (Fig. 5). Both compounds induced a significant $(P<0.01)$ increase in the $\mathrm{G} 2 / \mathrm{M}$ cell population with no significant changes in the $\mathrm{S}$ cell population. We observed a significant $(P<0.05$ for UDMA and $P<0.01$ for TEGDMA) decrease in the G0/G1 cell population. The combined action of UDMA and TEGDMA also resulted in a decrease in the G0/G1 cell population $(P<0.05)$, which was a comparable with the decrease with either compound singly.

\section{Discussion}

Genotoxic effects of xenobiotics are of a special significance because they may be characterized by a long latency period and they may have serious implications. The great majority of studies on the genotoxicity is performed with a substance acting alone. Such an attitude allows limiting a number of confounding factors in the analysis of data. However, the situation when we could take into account an exposure to just one factor or compound is very rare. Most often a complex exposure occurs, as in the case of composite dental materials, which are the complex of many compounds. That is why we investigated a combined action 
Fig. 4 Apoptosis of Chinese hamster ovary cells $\mathrm{CHO}-\mathrm{K} 1$ exposed for $6 \mathrm{~h}$ at $37^{\circ} \mathrm{C}$ to $1 \mathrm{mM}$ urethane dimethacrylate (UDMA, light gray bars), $5 \mathrm{mM}$ triethylene glycol dimethacrylate (TEGDMA, dark gray bars) singly or in combination (black bars) measured as a ratio of the number of early and late apoptotic cells to the number of cells with no measurable apoptosis. Apoptosis was assessed by flow cytometry with Annexin V-FITC/propidium iodine (PI). Displayed is the mean of three experiments of $5 \times 10^{4}$ measurements each, error bars denote standard deviation. The contour diagrams above the plot show one representative experiment out of three for each mode of exposure, with abscissa axis corresponding to V-FITC and ordinate axis - to PI. The lower left quadrant of each diagram shows the viable cells, which exclude PI and are negative for Annexin V-FITC binding. The upper right quadrant contain the non-viable, necrotic cells, positive for Annexin V-FITC binding and for PI uptake. The lower left quadrants represent the apoptotic cells, Annexin V-FITC positive and PI negative, demonstrating cytoplasmic membrane integrity. The mean \pm SEM is displayed; $* P<0.05$, *** $P<0.001$ as compared with unexposed control
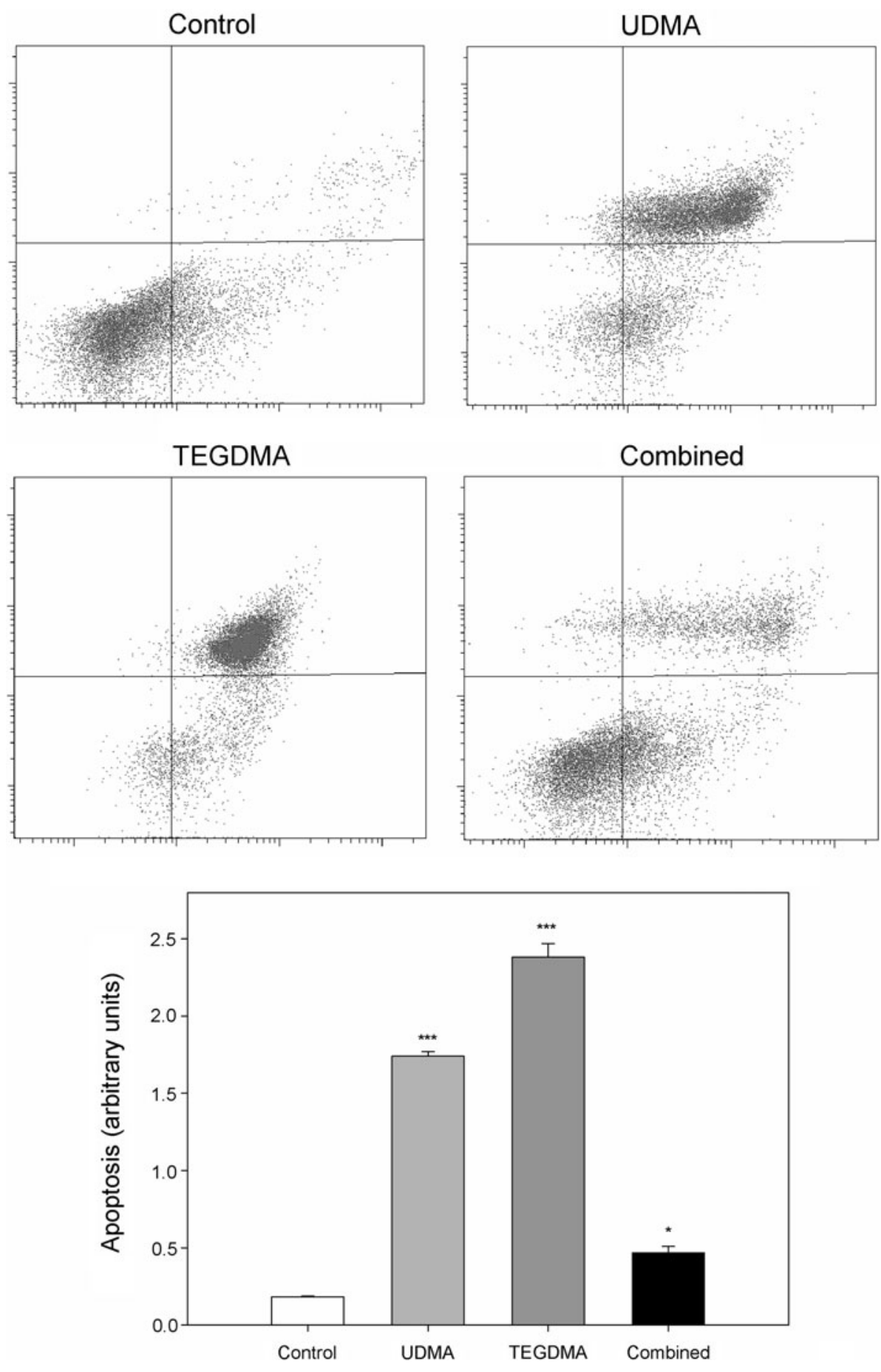

of UDMA, often used as a monomer, and TEGDMA, frequently applied as a co-monomer in dental composites.

Metahcrylate resin-based materials are increasingly applied in tooth restoration, due to their chemico-physical and aesthetic properties. These decided on their apparent advantages over traditional amalgam-based restorations, which can release mercury and are evidently toxic [21]. However, as mentioned in Introduction, methacrylate resin can release toxic monomers, so the introduction of methacrylate resin-based dental materials situated the old problem in new light-toxic mercury was changed into toxic methacrylates.

We used Chinese hamster ovary cells because they represent an established cell line for analysis of genotoxic effects [22-24]. It has been demonstrated that the composites are metabolised in the organism, producing toxic and radical 
Fig. 5 Cell cycle analysis of Chinese hamster ovary cells CHO-K1 exposed for $24 \mathrm{~h}$ at $37^{\circ} \mathrm{C}$ to $1 \mathrm{mM}$ urethane dimethacrylate (UDMA), $5 \mathrm{mM}$ triethylene glycol dimethacrylate (TEGDMA) singly or in combination. Percentage of cells in G0/G1 (white), S (gray) and G2/M (black) stages of the cell cycle after treatment with UDMA or/and TEGDMA was presented along with histograms for each mode of exposure. Nocodazole (Noc) was used as a positive control. Three experiments of $5 \times 10^{4}$ measurements each were performed. Data are expressed as means of three independent experiments, error bars denote $\mathrm{SD}, * P<0.05$, ** $P<0.01$ as compared with the unexposed control
Noc

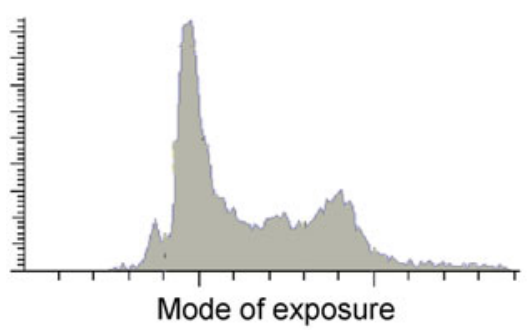

UDMA

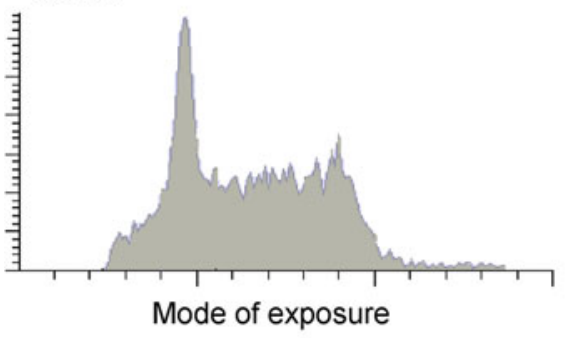

Combined
Control

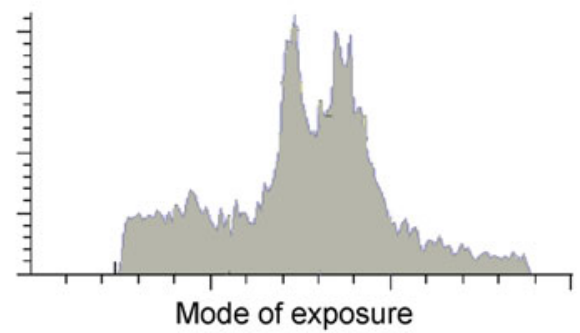

TEGDMA

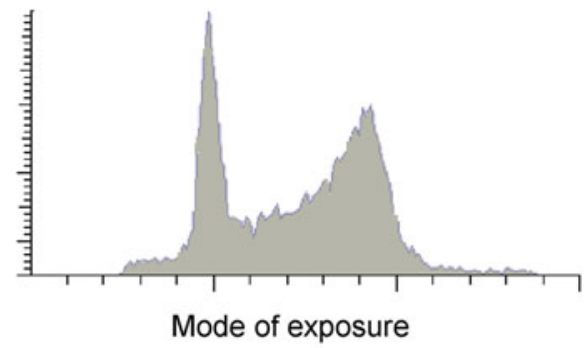

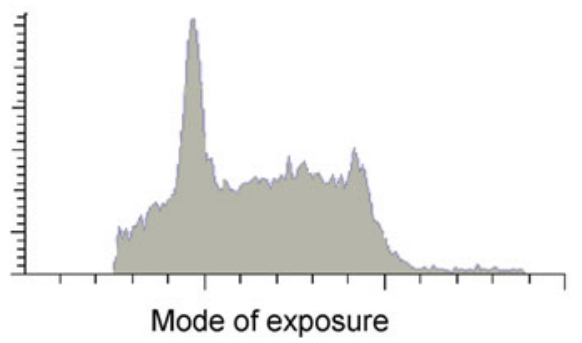

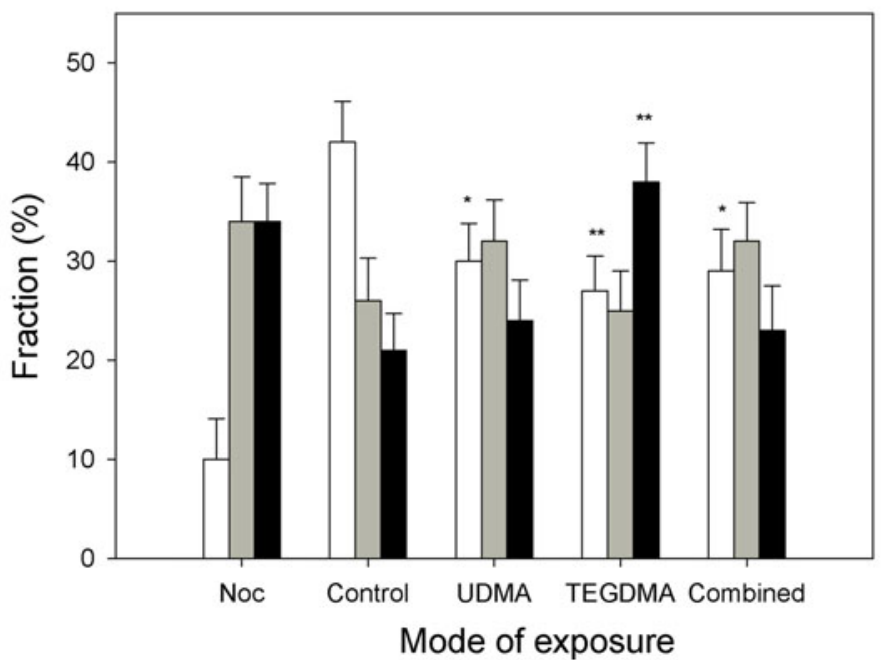

intermediates $[25,26]$. In the present work, we used two basic methacrylate dental restoration components, UDMA and TEGDMA at 1 and $5 \mathrm{mM}$, respectively. We chose such concentrations, as they were also applied in several other studies [6]. As mentioned in introduction, such high concentrations may be expected locally. Although such high concentrations may be expected locally, biological effect(s) associated with these concentrations may be systemic, as the pulp cells may penetrate with the blood stream to whole body. Moreover, in the present work we considered the genotoxic effects, which can be induced by a very low concentration, since a DNA-damaging effect in a single cell 
may result in its transformation, clonal expansion and the formation of tumor. Increasing concentration of a chemical is expected to increase the probability of such events, or, in other words, decrease the time needed to do so. However, sometimes two substances may act synergistically, producing a higher biological effect than is expected on the basis of their separate actions. This is particularly important, because substances considered as safe alone, may be harmful when acting in concert. We showed that UDMA and TEGDMA might not be safe, but their effects did not potentiate mutually and, therefore, their combined action probably would not bring a massive genotoxic effect, resulting in a high probability of mutations or cancer.

Experiments on the toxicity of dental materials are performed usually on one or more substances acting singly or commercial preparations in which the exact contents and technology of their production are confidential. Urcan et al. [14] showed recently, that monomer cytotoxicities increased in the order of Bis-GMA > UDMA > TEGDMA > HEMA in human gingival fibroblasts. Ratanasathien et al. [27] investigated the cytotoxicty of HEMA, Bis-GMA, UDMA and TEGDMA singly and in combination by the MTT assay. They found that TEGDMA and UDMA alone or in combination induced cytotoxic effects in mouse fibroblasts and they observed interactions between them, which (synergism, additivism or antagonism) depended on the concentrations and time of incubation. Therefore, multiple mechanisms may underline the toxicity of UDMA and TEGDMA, and each mechanism might have its own specificity, acting at specific concentrations and time conditions. In the present work, we showed that UDMA at $1 \mathrm{mM}$ and TEGDMA at $5 \mathrm{mM}$ may exert a significant genotoxic effect when they acted separately (Fig. 3). Their combined action was not additive, since the joined effect of both agents was only slightly higher than the effect of TEGDMA acting singly.

It is interesting to take a closer look at the results from apoptosis study, as they indicate that the combined action of UDMA and TEGDMA differed significantly from the action of either compound alone and from an anticipated additive action of both compounds (Fig. 4). In particular, the population of early apoptotic cells produced by the combined action was larger than that followed from the action of TEGDMA, but was comparable with that produced by UDMA. Therefore, we can consider an additive action of both compounds in the initiating of the process of apoptosis. However, dramatic changes were observed in the fraction of viable cells (PI and Annexin V negative)this fraction was very small after the exposure to TEGDMA and was a major fraction on the incubation with UDMA, but constituted the main fraction after combined action of both compounds. The fraction of cells in late apoptosis or necrosis (Annexin V-FTIC and PI positive) was the main fraction upon the action of TEGDMA and
UDMA singly, but it became a minor fraction after the combined action of these compounds. Therefore, we can conclude that there may be a chemical interaction between UDMA and TEGDMA which can be mediated by cellular structures. This interaction may lead to a partial inactivation of both compounds, leading to diminishing their cytotoxic capacity. The same, although in a lesser degree, may concern their ability to induce genotoxic effects.

We observed the influence of both UDMA and TEGDMA on the cell cycle progression in CHO cells (Fig. 5). This can be linked with the observed DNA-damaging effects of these compounds (Fig. 3). DNA damage may induce several cellular reactions, first of all DNA repair, and such reaction may interfere with the successful completion of G1, S and G2 phases of the cell cycle. In particular, when DNA damage is too massive to be repaired by the cell before entering mitosis, the G2/M checkpoint may be activated to stop the progression of the cell cycle. Similar checkpoints may be activated between G1 and S phases of the cycle, which cause cell cycle delay as reported by Schweikl et al. on various cell lines incubated with TEGDMA [28].

\section{Conclusion}

UDMA and TEGDMA may exert significant cytotoxic and genotoxic effects and they may interact, producing effects different from those expected from their action alone. The mechanisms underlying this interaction may be complex and needs further study.

Acknowledgments This work was supported by the grant N N401 223124 from the Ministry of Science and Higher Education. We thank Ms. Monika Kicinska for helping us to prepare the manuscript.

Open Access This article is distributed under the terms of the Creative Commons Attribution Noncommercial License which permits any noncommercial use, distribution, and reproduction in any medium, provided the original author(s) and source are credited.

\section{References}

1. Gerzina TM, Hume WR (1996) Diffusion of monomers from bonding resin-resin composite combinations through dentine in vitro. J Dent 24:125-128

2. Pelka M, Distler W, Petschelt A (1999) Elution parameters and HPLC-detection of single components from resin composite. Clin Oral Investig 3:194-200

3. Geurtsen W (2000) Biocompatibility of resin-modified filling materials. Crit Rev Oral Biol Med 11:333-355

4. Rueggeberg FA, Caughman WF (1993) The influence of light exposure on polymerization of dual-cure resin cements. Oper Dent 18:48-55

5. Spahl W, Budzikiewicz H, Geurtsen W (1998) Determination of leachable components from four commercial dental composites 
by gas and liquid chromatography mass spectrometry. J Dent 26:137-145

6. Schweikl H, Spagnuolo G, Schmalz G (2006) Genetic and cellular toxicology of dental resin monomers. J Dent Res 85: 870-877

7. Noda M, Wataha JC, Kaga M, Lockwood PE, Volkmann KR, Samo H (2002) Components of dentinal adhesives modulate heat shock protein 72 expression in heat-stressed THP-1 human monocytes at sublethal concentrations. J Dent Res 81:265-269

8. Bouillaguet S, Wataha JC, Hanks CT, Ciucchi B, Holz J (1996) In vitro cytotoxicity and dentin permeability of HEMA. J Endod 22:244-248

9. Kanerva L (2001) Cross-reactions of multifunctional methacrylates and acrylates. Acta Odontol Scand 59:320-329

10. Alanko K, Susitaival P, Jolanki R, Kanerva L (2004) Occupational skin diseases among dental nurses. Contact Derm 50:77-82

11. Schweikl H, Schmalz G (1999) Triethylene glycol dimethacrylate induces large deletions in the hprt gene of V79 cells. Mutat Res 438:71-78

12. Kleinsasser NH, Wallner BC, Harreus UA, Kleinjung T, Folwaczny M, Hickel R et al (2004) Genotoxicity and cytotoxicity of dental materials in human lymphocytes as assessed by the single cell microgel electrophoresis (comet) assay. J Dent 32:229-234

13. Poplawski T, Pawlowska E, Wisniewska-Jarosinska M, Ksiazek D, Wozniak K, Szczepanska J (2009) Cytotoxicity and genotoxicity of glycidyl methacrylate. Chem Biol Interact 180:60-78

14. Urcan E, Scherthan H, Styllou M, Haertel U, Hickel R, Reichl F$X$ (2010) Induction of DNA double-strand breaks in primary gingival fibroblasts by exposure to dental resin composites. Biomaterials 31:2010-2014

15. Assumption HJ, Mathias LJ (2003) Photopolymerization of urethane dimethacrylates synthesized via a non-isocyanate route. Polymer 44:5131-5136

16. Kainthla R, Zewail-Foote M (2008) Oxidative DNA damage following photoexcitation of daunomycin: direct role of oxygen. J Photochem Photobiol A 198:200-204
17. Singh NP, McCoy MT, Tice RR, Schneider EL (1988) A simple technique for quantification of low levels of DNA damage in individual cells. Exp Cell Res 175:184-191

18. Klaude M, Eriksson S, Nygren J, Ahnstrom G (1996) The comet assay: mechanisms and technical considerations. Mutat Res 12:89-96

19. Singh NP, Stephens RE (1997) Microgel electrophoresis: sensitivity, mechanisms and DNA electrostretching. Mutat Res 383:167-175

20. Tice RR, Agurell E, Anderson D, Burlinson B, Hartmann A, Kobayashi $\mathrm{H}$ et al (2000) Single cell gel/comet assay: guidelines for in vitro and in vivo genetic toxicology testing. Environ Mol Mutagen 35:206-221

21. Horstedt-Bindslev P (2004) Amalgam toxicity—environmental and occupational hazards. J Dent 32:359-365

22. Marins JS, Sassone LM, Ribeiro DA (2009) Biopure MTAD induces DNA damage but not cellular death: an in vitro study. Eur J Dent 3:285-289

23. Tavares JC, Cornélio DA, da Silva NB, de Moura CE, de Queiroz JD, Sá JC et al (2009) Effect of titanium surface modified by plasma energy source on genotoxic response in vitro. Toxicology 262:138-145

24. Yang HW, Chou LS, Chou MY, Chang YC (2003) Assessment of genetic damage by methyl methacrylate employing in vitro mammalian test system. Biomaterials 24:2909-2914

25. Burtscher P (1993) Stability of radicals in cured compositematerials. Dent Mater 4:218-221

26. Durner J, Walther UI, Zaspel J, Hickel R, Reichl FX (2010) Metabolism of TEGDMA and HEMA in human cells. Biomaterials 31:818-823

27. Ratanasathien S, Wataha JC, Hanks CT, Dennison JB (1995) Cytotoxic interactive effects of dentin bonding components on mouse fibroblasts. J Dent Res 74:1602-1606

28. Schweikl H, Altmannberger I, Hanser N, Hiller KA, Bolay C, Brockhoff G (2005) The effect of triethylene glycol dimethacrylate on the cell cycle of mammalian cells. Biomaterials 26:4111-4118 